\title{
Which is the best environment for the development of the early life stages of fish during the dry season?
}

Qual o melhor ambiente para o desenvolvimento

das fases jovens de peixes durante a estação seca?

\section{André Luiz Henríques Esguícero and Marlene Sofia Arcifa}

Departamento de Biologia, Universidade de São Paulo, Av. Bandeirantes, 3900,

CEP 14040-901, Ribeirão Preto, SP, Brazil

e-mail: andre.esguicero@gmail.com,marcifa@usp.br

\begin{abstract}
Aim: The main objective of this study was to investigate the quality of habitats for early life stages of fish in the Jacaré-Guaçu River, during the dry phase; Methods: For assessing the quality of the habitats for the development of early life stages, the relative condition factor was applied to the juveniles of five species of fishes, captured in four different habitats (reservoir, floodplain lake, main river, and tributary). The juveniles were caught in macrophytes of the littoral zone by a rectangular sieve, in the dry season of 2008 and 2009; Results: The species Astyanax altiparanae thrived similarly in the four habitats, and A. fasciatus, Hyphessobrycon eques, Hoplias malabaricus and Serrapinnus notomelas, showed higher values of relative condition factors in the reservoir and in the lake. Among the species, A. fasciatus showed the highest values of the relative condition factor in these two habitats; Conclusions: It is likely that the complexity of the macrophytes' stands and the current velocity were the main factors influencing the development of juveniles. It was found that a lower current velocity can propitiated the establishment of a greater richness of macrophytes, which in turn can influence positively the development of fish juveniles. Moreover, a higher current velocity ends in a higher energy demand for swimming.
\end{abstract}

Keywords: Upper Paraná River Basin, Neotropical Characiformes, fish nurseries, nutritional condition.

Resumo: Objetivo: O objetivo principal deste estudo foi investigar a qualidade dos habitats para as primeiras fases de vida dos peixes no Rio Jacaré-Guaçu, durante a estação seca; Métodos: Para avaliar a qualidade dos hábitats para o desenvolvimento das primeiras fases, o fator de condição relativo foi aplicado aos juvenis de cinco espécies de peixes, capturados em quatro habitats diferentes (reservatório, lago de planície de inundação, canal principal e tributário). Os juvenis foram coletados em macrófitas litorâneas com uma peneira retangular, na estação seca de 2008 e 2009; Resultados: Somente Astyanax altiparanae se desenvolveu similarmente bem nos quatro hábitats, sendo que as outras, A. fasciatus, Hyphessobrycon eques, Hoplias malabaricus e Serrapinnus notomelas, tiveram maiores valores do fator de condição relativo no reservatório e no lago. Entre as espécies, $A$. fasciatus foi a que apresentou os maiores valores do fator de condição relativo nesses dois hábitats; Conclusóes: É provável que a complexidade dos bancos de macrófitas e a velocidade da corrente tenham sido os fatores que mais influenciaram o desenvolvimento dos juvenis. Foi verificado que habitats de baixa correnteza podem permitir o estabelecimento de uma maior riqueza de macrófitas, o que por sua vez pode influenciar positivamente o desenvolvimento de juvenis de peixes. Além disso, hábitats com correntezas maiores provavelmente demandam um maior custo energético para a natação.

Palavras-chave: Bacia do Alto Rio Paraná, Characiformes Neotropicais, criadouros de peixes, condição nutricional. 


\section{Introduction}

Pluviometric fluctuations and wind regime lead tropical rivers to seasonal variations, resulting in two distinct phases, a high water phase and a dry one (Lowe-McConnell, 1999; Thomaz et al., 1997). During the high water phase, the lateral expansion of rivers into a floodplain, with lakes and flooded areas, are of fundamental importance for the reproductive success of the fish fauna. These habitats nourish and shelter early life stages of fishes, whose faster development allows juveniles to reduce the predation risk (Vazzoler, 1996; Vazzoler et al., 1997), and play the role of nurseries for several fishes (Nakatani et al., 2001).

Some species, however, mostly non-migratory ones, are able to reproduce also during the dry phase, although with lower intensity (Vazzoler, 1996). Flooded areas and temporary floodplain lakes disappear during the dry phase, reducing drastically the nursing habitats for the early stages. The species, which reproduce during this phase, face a lower choice of habitats and lower abundance of food resources for their offsprings.

Macrophytes harbor a large diversity of invertebrates (Takeda et al., 2003) and fishes (Agostinho et al., 2003; Sánchez-Botero and Araújo-Lima, 2001), which are sheltered by the structural complexity of the plants. In Brazilian reservoirs and floodplain lakes, macrophytes are more densely populated by fishes, namely juveniles and adults of small species (review by Agostinho et al., 2003; Meschiatti et al., 2000a). The littoral zone of Brazilian lentic water bodies are more heavily inhabited by fishes than the limnetic one (Arcifa et al., 1988; review by Arcifa and Northcote, 1997; Arcifa and Meschiatti, 1993), and juveniles are not caught in the open area (Meschiatti et al., 2000a; Meschiatti and Arcifa, 2002).

Studies on the ecology of early life stages of fishes are fundamental for the understanding of population dynamics. The relevance of these studies exceeds the limits of basic knowledge, because they can contribute to the increase of fish production, management and conservation measures, and impact evaluation (Nakatani et al., 2001).

The objectives of this study were to investigate the quality of habitats for early life stages of five fish species in the Jacaré-Guaçu River, during the dry phase. During the dry season food resources are not as abundant as in the high water phase (Vazzoler and Menezes, 1992), and habitats are reduced. Based on Vazzoler (1996), habitats that provide greater food availability and shelter, even during the dry season, will probably be suitable for the development of early life stages of fish. So, to achieve our purpose, the relationship length-weight was used as a tool for evaluating the quality of distinct habitats for the fish juveniles. Also denominated Condition Factor, this relationship is basic for the biological, physiological, and ecological studies, for reflecting the interactions between fishes and abiotic and biotic factors (Gomiero and Braga, 2003; Lizama and Ambrósio, 2002; Vazzoler, 1996).

\section{Material and Methods}

\subsection{Study area}

Four habitats were selected in the Jacaré-Guaçu basin (Figure 1), a tributary of the right margin of the Tietê River, from the Upper Paraná River. The stretch studied is located between Gavião Peixoto Dam, closed in 1913, and Santana Dam, closed in 1958. The habitats were (Figure 1): A. the reservoir (21. 50' 46” S, 48' 29' 22” W); B. a river stretch

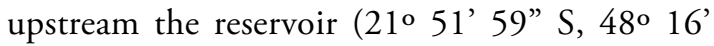
$\left.42^{\prime \prime} \mathrm{W}\right)$; C. a floodplain lake (210 51' $53^{\prime \prime} \mathrm{S}, 48^{\circ}$ $\left.16^{\prime} 42^{\prime} \mathrm{W}\right)$ permanently connected to the river; D. Chibarro River (21 51' 52” S, 48 16'09” W), a tributary of the right margin of the Jacaré-Guaçu River.

Each habitat was surveyed for characterizing (Table 1): the richness of macrophytes, expressed as the number of species; the margins and their vegetation; average depth, measured at the littoral zone; the substrate type of the bottom; the width or the area of the water body; and the current velocity, which was estimated by the method of a floating object (Brower and Zar, 1977). Other abiotic factors measured were the Secchi disk-transparency with a $30 \mathrm{~cm}$-white disk, temperature, dissolved oxygen, electrical conductivity at $25^{\circ} \mathrm{C}$, and $\mathrm{pH}$ with Yellow Springs Inc. equipment. The mean data were calculated from pooling the two periods.

\subsection{Sampling}

Samplings were carried out in two periods during the dry season, the first from 22 to 25/June/2008, and the second from 21 to 24/June/2009. Fishes were caught within the macrophytes near their border, with a rectangular sieve, measuring $100 \times 70 \mathrm{~cm}$, provided with a $5 \mathrm{~mm}$ meshed net, between adjacent knots. For comparable data, the effort was standardized, the rectangular sieve being used 20 times in each studied site. The specimens were fixed with $10 \%$ formalin and then transferred to $70 \%$ ethanol. In the laboratory, specimens 

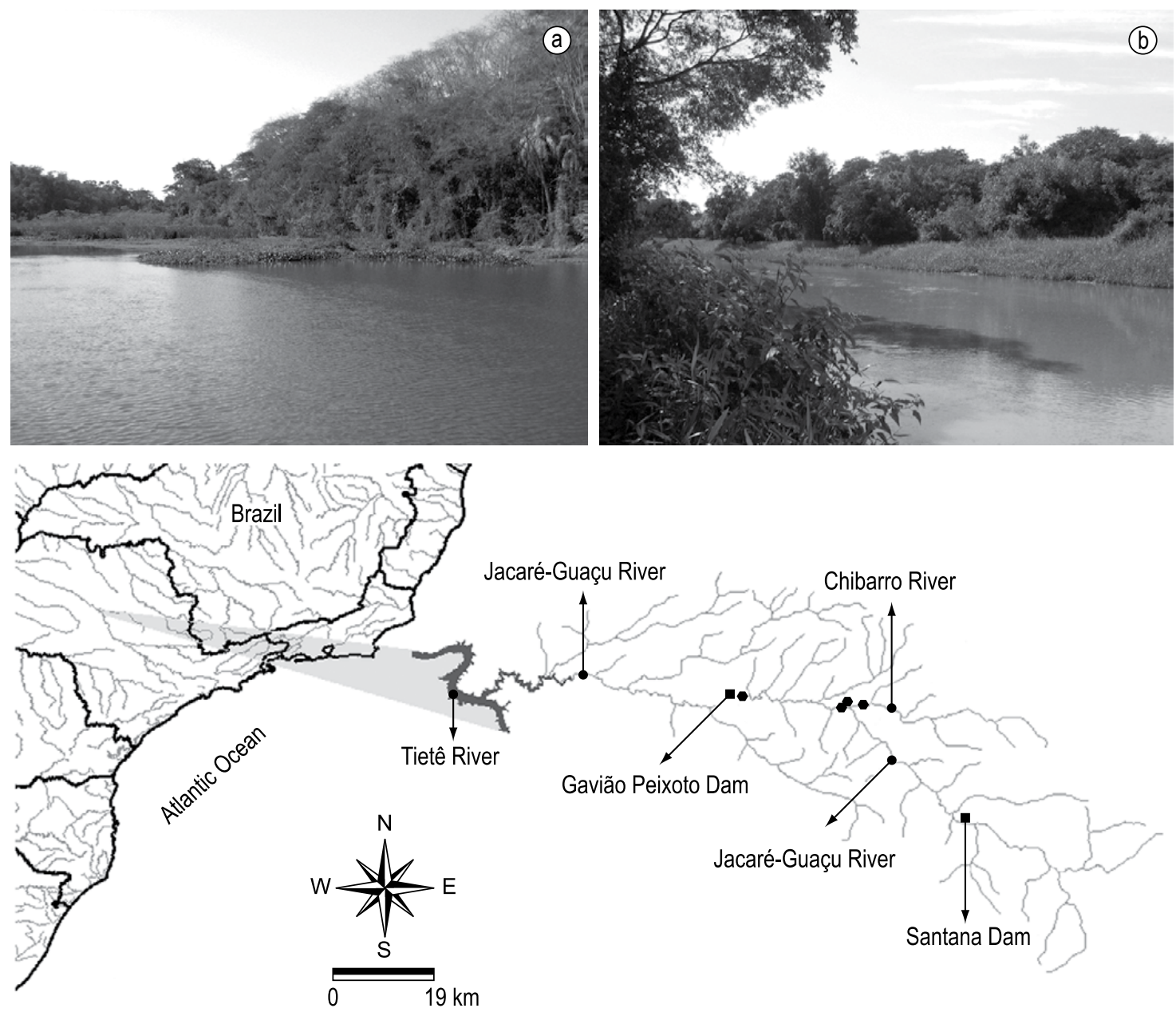

Gavião Peixoto Dam

Jacaré-Guaçu River
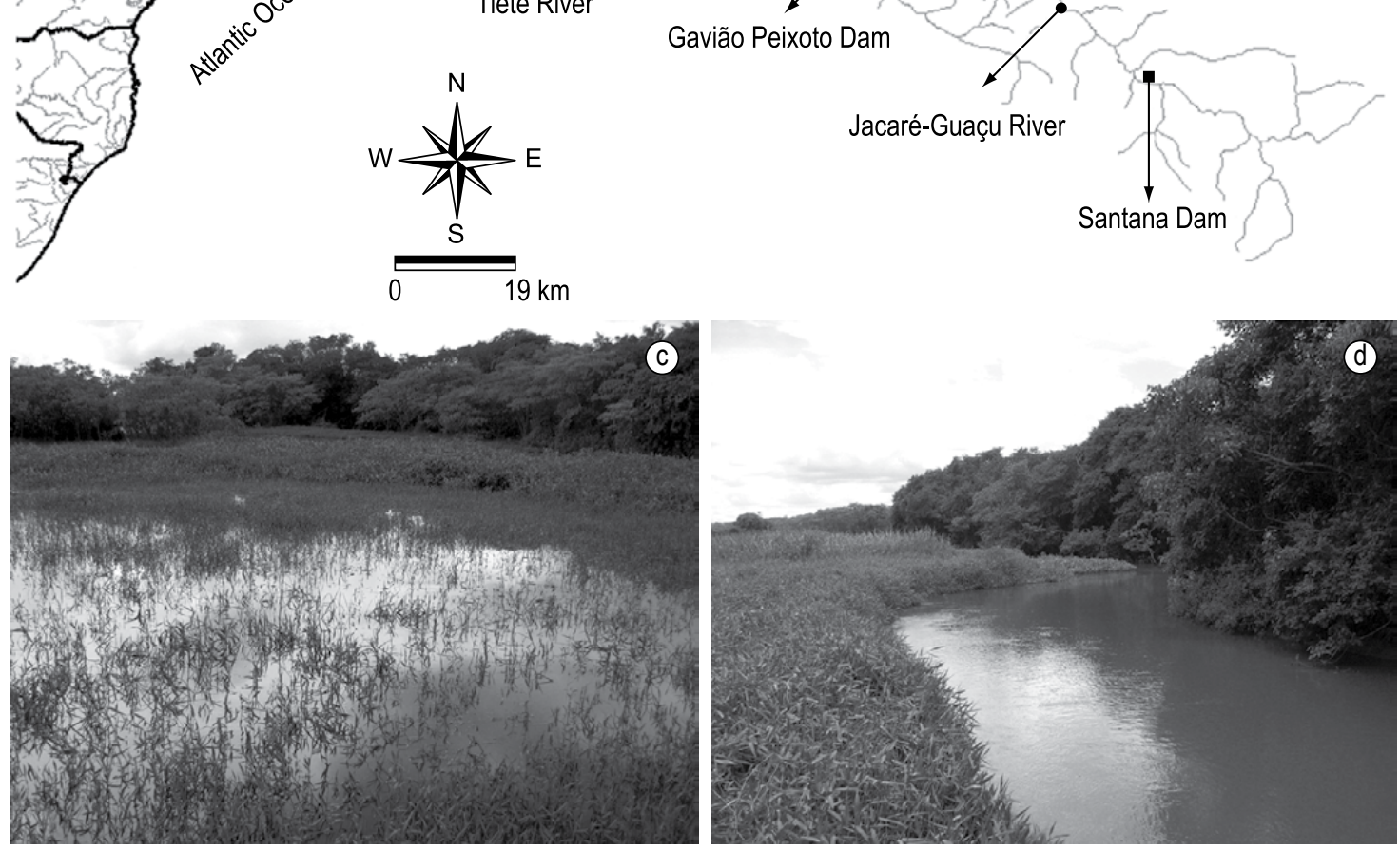

Figure 1. Location of the Jacaré-Guaçu basin in Brazil and of the four habitats in the Jacaré-Guaçu basin and their pictures: a) The reservoir of Gavião Peixoto Dam; b) Jacaré-Guaçu River; c) floodplain lake; d) Chibarro River.

were weighed on a digital balance and measured (standard length - SL) with a caliper rule.

\subsection{Statistical analyses}

The relative condition factor $(\mathrm{Kn})$ (Le Cren, 1951) was applied for evaluating the quality of the habitats for maintaining early stages of five fish species, Astyanax altiparanae Garutti \& Britski, 2000, Astyanax fasciatus (Cuvier, 1819), Hoplias malabaricus (Bloch, 1794), Hyphessobrycon eques (Steindachner, 1882), and Serrapinnus notomelas (Eigenmann, 1915). Both adults and juveniles of most of these species were collected in the sites, but only juveniles were used 
Table 1. Characteristics of the four studied habitats in the Jacaré-Guaçu River Basin: a) reservoir of Gaviáo Peixoto Dam; b) Jacaré-Guaçu River; c) floodplain lake; d) Chibarro River. The mean data ( \pm standard error) were calculated from pooling the two studied periods (22-25/June/2008 and 21-24/June/2009).

\begin{tabular}{|c|c|c|c|c|}
\hline Habitats & $\mathrm{A}$ & $B$ & $C$ & $\mathrm{D}$ \\
\hline $\begin{array}{l}\text { Current } \\
\text { Velocity }\end{array}$ & $\begin{array}{l}0.11 \mathrm{~m} / \mathrm{s} \\
( \pm 0.01)\end{array}$ & $\begin{array}{l}0.34 \mathrm{~m} / \mathrm{s} \\
( \pm 0.02)\end{array}$ & $0 \mathrm{~m} / \mathrm{s}$ & $\begin{array}{l}0.39 \mathrm{~m} / \mathrm{s} \\
( \pm 0.03)\end{array}$ \\
\hline $\begin{array}{l}\text { Water } \\
\text { Transparency }\end{array}$ & $\begin{array}{l}1.15 \mathrm{~m} \\
( \pm 0.07)\end{array}$ & $\begin{array}{l}0.64 \mathrm{~m} \\
( \pm 0.03)\end{array}$ & total & $\begin{array}{l}0.44 \mathrm{~m} \\
( \pm 0.05)\end{array}$ \\
\hline $\begin{array}{l}\text { Dissolved } \\
\text { Oxygen }\end{array}$ & $\begin{array}{l}7.52 \mathrm{mg} / \mathrm{l} \\
( \pm 0.07)\end{array}$ & $\begin{array}{c}6.44 \mathrm{mg} / \mathrm{l} \\
( \pm 0.03)\end{array}$ & $\begin{array}{l}6.19 \mathrm{mg} / \mathrm{l} \\
( \pm 0.06)\end{array}$ & $\begin{array}{l}7.62 \mathrm{mg} / \mathrm{l} \\
( \pm 0.17)\end{array}$ \\
\hline $\begin{array}{l}\text { Water } \\
\text { Conductivity }\end{array}$ & $\begin{array}{l}76.1 \mu \mathrm{S} / \mathrm{cm} \\
( \pm 1.8)\end{array}$ & $\begin{array}{c}60.5 \mu \mathrm{S} / \mathrm{cm} \\
( \pm 0.6)\end{array}$ & $\begin{array}{c}49.1 \mu \mathrm{S} / \mathrm{cm} \\
( \pm 0.7)\end{array}$ & $\begin{array}{l}138.7 \mu \mathrm{S} / \mathrm{cm} \\
( \pm 5.7)\end{array}$ \\
\hline $\begin{array}{l}\text { Water } \\
\text { Temperature }\end{array}$ & $\begin{array}{l}16.8^{\circ} \mathrm{C} \\
( \pm 0.1)\end{array}$ & $\begin{array}{l}14.5^{\circ} \mathrm{C} \\
( \pm 0.4)\end{array}$ & $\begin{array}{l}12.2^{\circ} \mathrm{C} \\
( \pm 0.4)\end{array}$ & $\begin{array}{l}19.9^{\circ} \mathrm{C} \\
( \pm 0.3)\end{array}$ \\
\hline $\mathrm{pH}$ & $\begin{array}{c}6.6 \\
( \pm 0.04)\end{array}$ & $\begin{array}{c}6.3 \\
( \pm 0.03)\end{array}$ & $\begin{array}{c}5.5 \\
( \pm 0.1)\end{array}$ & $\begin{array}{c}7.6 \\
( \pm 0.21)\end{array}$ \\
\hline Depth & $\begin{array}{l}1.75 \mathrm{~m} \\
( \pm 0.01)\end{array}$ & $\begin{array}{l}1.4 \mathrm{~m} \\
( \pm 0.11)\end{array}$ & $\begin{array}{c}0.7 \mathrm{~m} \\
( \pm 0.04)\end{array}$ & $\begin{array}{c}1.0 \mathrm{~m} \\
( \pm 0.13)\end{array}$ \\
\hline Substrate & $\begin{array}{l}\text { muddy and decomposing } \\
\text { organic matter }\end{array}$ & mud and sand & $\begin{array}{l}\text { muddy and decomposing } \\
\text { organic matter }\end{array}$ & muddy \\
\hline Macrophytes & $\begin{array}{l}\text { Salvinia auriculata } \\
\text { S. biloba } \\
\text { Pistia stratiotes } \\
\text { Eichornia azurea } \\
\text { Floscopa glabrata } \\
\text { Typha domingensis } \\
\text { Brachiaria spp. }\end{array}$ & Brachiaria spp. & $\begin{array}{l}\text { S. auriculata } \\
\text { S. biloba } \\
\text { P. stratiotes } \\
\text { E. azurea } \\
\text { F. glabrata } \\
\text { Brachiaria spp. }\end{array}$ & Brachiaria spp. \\
\hline $\begin{array}{l}\text { Margin } \\
\text { Declivity }\end{array}$ & low & low & low & low \\
\hline $\begin{array}{l}\text { Riparian } \\
\text { Vegetation }\end{array}$ & partially preserved & partially preserved & partially preserved & $\begin{array}{l}\text { right margin - preserved } \\
\text { left margin - absent }\end{array}$ \\
\hline $\begin{array}{l}\text { River Width/ } \\
\text { Lake Area }\end{array}$ & $95 \mathrm{~m}$ & $25 \mathrm{~m}$ & $490 \mathrm{~m}^{2}$ & $7 \mathrm{~m}$ \\
\hline
\end{tabular}

in this study. These species were chosen because they were the most abundant and frequent in the studied habitats.

The relative condition factor $(\mathrm{Kn})$ (Le Cren, 1951) was used to investigate which is the best habitat for the development of the early life stages of fish, during the dry season, and compare the performance of the species in each habitat. For all individuals the equation used was: $\mathrm{Kn}=\mathrm{W}_{\mathrm{t}} / \mathrm{W}_{\mathrm{e}}$, where $\mathrm{W}_{\mathrm{t}}$ = total weight and $\mathrm{W}_{\mathrm{e}}=$ expected weight, which was calculated by $\mathrm{W}_{\mathrm{e}}=\mathrm{aSL}{ }^{\mathrm{b}}$, where $\mathrm{SL}=$ standard length and $b=$ angular coefficient of the regression between W/SL (Lizama et al., 1999; Vazzoler, 1996). The intercept (a) and the angular coefficient (b) were estimated by log transformation of length and weight and adjustement of a straight line using the method of minimum squares (Gomiero and Braga, 2003). Average Kn was obtained for each species, and the means were compared using ANOVA and the post hoc Tukey test. The statistical significance of the differences between the average $\mathrm{Kn}$ and the expected average $\mathrm{Kn}(\mathrm{Kn}=1)$ was obtained by the Student's t-test.

The influences of physical and chemical factors on the juveniles' Kn were evaluated by the Pearson's correlation analysis, using the average values of the physical and chemical factors of each habitat, and the richness of macrophytes. All the statistical analyses were performed using the statistical program Past 1.90 (Hammer et al., 2001).

\section{Results}

The floodplain lake and the reservoir are habitats of lower current velocities and higher macrophyte richness (Table 1). Dissolved oxygen concentrations were relatively high in all habitats, and $\mathrm{pH}$ values ranged from 5.5 to 7.6. In both rivers, JacaréGuaçu and Chibarro, there was a lower diversity of macrophytes than in the other two habitats, with 
the predominance of the exotic grass Brachiaria spp. (Poaceae).

Astyanax altiparanae, A. fasciatus, Hoplias malabaricus, Hyphessobrycon eques, and Serrapinnus notomelas (Table 2) were the five most abundant and frequent species in the four habitats. There was a trend for higher abundance of juveniles in the floodplain lake for four of the five species. A similar number of $H$. malabaricus was caught in all habitats.

There were no significant differences (post hoc Tukey test, $P<0.1)$ between the relative condition factors of the species in the two sampling periods (Figure 2). Therefore, the data of the periods were pooled and the means were used for comparisons.

The relative condition factor highlighted the better quality of the lentic or semi-lentic habitats (reservoir and lake) for all the species (Figure 3), except for $A$. altiparanae, which showed similar Kn values in the four habitats. In general, the reservoir was a suitable habitat for the juveniles of all species, the lake offering similar quality for three species, A. fasciatus, $H$. malabaricus, and $S$. notomelas. Except for $A$. altiparanae, both rivers, Jacaré-Guaçu and Chibarro, offered more adverse conditions than the other habitats for juveniles. Among the species, $A$. fasciatus was the most successful one in the reservoir and the lake (Figure 4).

Since $A$. altiparanae showed no Kn variation among the habitats, the Pearson's correlation analysis was performed with the other four species. The Kn values of the four species were positively correlated with the macrophyte richness and negatively correlated with the current velocity (Table 3 ), and showed no significant correlation with the other tested variables. Besides, macrophyte richness and the current velocity were negatively correlated $(\mathrm{r}=-0.925, P=0.046)$. So, lower current velocity can favor the establishment of greater macrophyte richness, as reported by Camargo et al. (2003), which in turn can propitiate higher Kn values for juveniles.

\section{Discussion}

During the early phases, fishes expend most energy with the linear growth and the development of somatic structures (Vazzoler, 1996). Therefore, the welfare of juveniles is intrinsically related to the environmental conditions and their adaptation to them. Several habitat features can affect the welfare of juveniles, such as food quantity and quality, deseases, parasites, competition, and predation
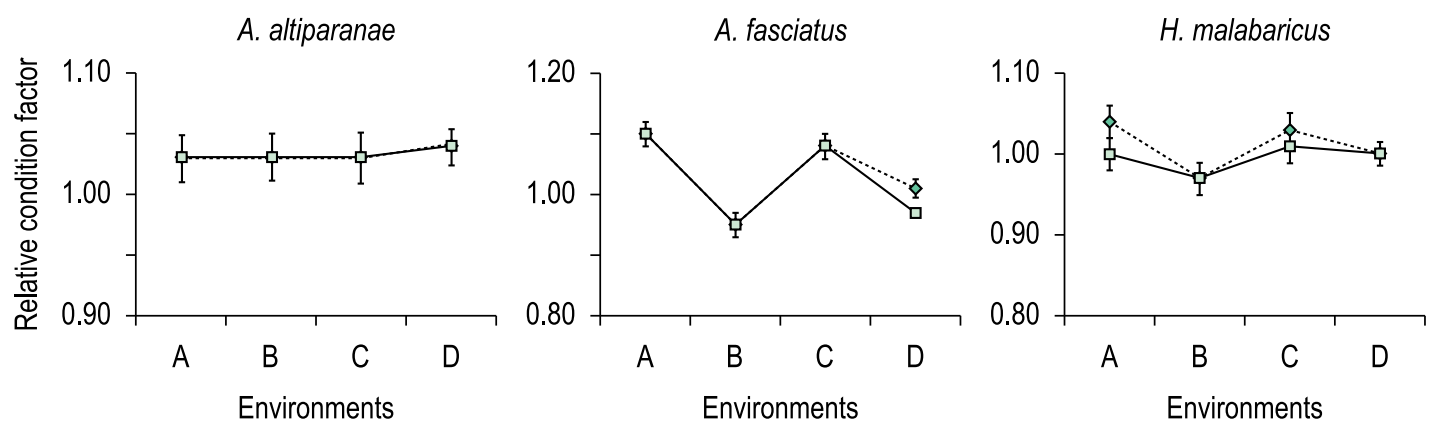

$H$. eques
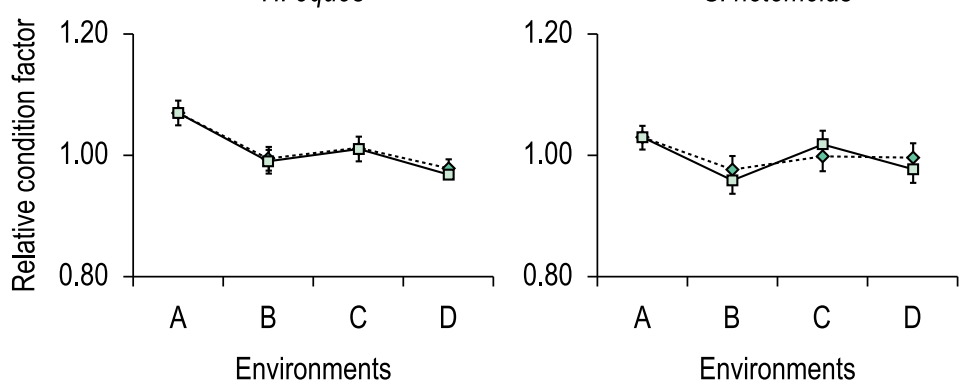

June $2008-\square-$ June 2009

Figure 2. Comparison of the average relative condition factors (with standard error) of the five species, in each period in the four habitats: a) The reservoir of Gavião Peixoto Dam; b) Jacaré-Guaçu River; c) floodplain lake; d) Chibarro River. 
Table 2. Abundant and frequent species studied in the habitats: a) Gavião Peixoto Reservoir, b) Jacaré-Guaçu River, c) Floodplain lake, d) Chibarro River. $N$ - number of young specimens caught: $N_{1}$ - period 22-25/June/2008 and $\mathrm{N}_{2}$ - period 21-24/June/2009. SL - standard length.

\begin{tabular}{|c|c|c|c|c|c|c|c|c|c|}
\hline \multirow[t]{3}{*}{ Species } & \multirow{3}{*}{$\begin{array}{c}\mathrm{SL} \\
(\mathrm{mm})\end{array}$} & \multicolumn{8}{|c|}{ Environments } \\
\hline & & \multicolumn{2}{|c|}{ A } & \multicolumn{2}{|c|}{ B } & \multicolumn{2}{|c|}{$C$} & \multicolumn{2}{|c|}{$D$} \\
\hline & & $\mathrm{N}_{1}$ & $\mathrm{~N}_{2}$ & $\mathrm{~N}_{1}$ & $\mathrm{~N}_{2}$ & $\mathrm{~N}_{1}$ & $\mathrm{~N}_{2}$ & $\mathrm{~N}_{1}$ & $\mathrm{~N}_{2}$ \\
\hline A. altiparanae & $11.1-33.4$ & 42 & 37 & 27 & 31 & 57 & 62 & 32 & 34 \\
\hline A. fasciatus & $13.7-41.5$ & 33 & 29 & 28 & 32 & 34 & 36 & 22 & 27 \\
\hline H. malabaricus & $36.2-77.3$ & 12 & 11 & 9 & 13 & 11 & 14 & 10 & 13 \\
\hline H. eques & $9.8-12.1$ & 67 & 78 & 22 & 24 & 57 & 55 & 18 & 29 \\
\hline S. notomelas & $10.6-16.2$ & 72 & 61 & 32 & 33 & 68 & 66 & 22 & 14 \\
\hline
\end{tabular}

Table 3. Pearson's Correlation between the relative condition factor of juveniles and some characteristics of the studied sites (Figure 1). The statistically significant values are presented in bold.

\begin{tabular}{|c|c|c|c|c|c|c|c|c|}
\hline \multirow[t]{2}{*}{ Variables } & \multicolumn{2}{|c|}{ A. fasciatus } & \multicolumn{2}{|c|}{ H. malabaricus } & \multicolumn{2}{|c|}{ H. eques } & \multicolumn{2}{|c|}{ S. notomelas } \\
\hline & $r$ & $P$ & $r$ & $P$ & $r$ & $P$ & $r$ & $P$ \\
\hline Current Velocity $(\mathrm{m} / \mathrm{s})$ & -0.880 & 0.012 & -0.767 & 0.023 & -0.748 & 0.042 & -0.728 & 0.027 \\
\hline Dissolved Oxygen (mg/l) & 0.101 & 0.899 & 0.223 & 0.777 & -0.009 & 0.991 & 0.352 & 0.648 \\
\hline Electrical Conductivity $(\mu \mathrm{S} / \mathrm{cm})$ & -0.303 & 0.697 & -0.043 & 0.957 & -0.570 & 0.430 & -0.062 & 0.938 \\
\hline Water Temperature $\left({ }^{\circ} \mathrm{C}\right)$ & -0.240 & 0.760 & -0.058 & 0.942 & -0.275 & 0.725 & 0.019 & 0.981 \\
\hline $\mathrm{pH}$ & -0.391 & 0.609 & -0.204 & 0.796 & -0.336 & 0.664 & -0.139 & 0.861 \\
\hline Depth (m) & 0.056 & 0.944 & -0.158 & 0.842 & 0.524 & 0.170 & 0.137 & 0.863 \\
\hline Macrophytes' Richness & 0.974 & 0.026 & 0.848 & 0.015 & 0.830 & 0.047 & 0.898 & 0.012 \\
\hline
\end{tabular}

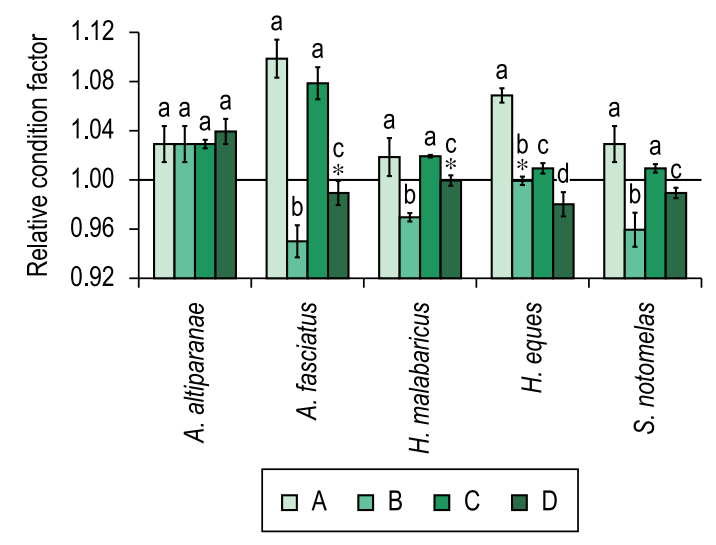

Figure 3. Comparison of the average relative condition factors (with standard error) of the five species, pooling the data of the two periods, in the four habitats: a) The reservoir of Gavião Peixoto Dam; b) Jacaré-Guaçu River; c) floodplain lake; d) Chibarro River. Different letters above bars indicate significant differences among Kn of the species in each habitat (post hoc Tukey test, $P<0.05$ ), and ${ }^{*}$ indicates no statistical difference from 1 (Student's t-test, $P<0.05)$; the gray line indicates the default value $(\mathrm{Kn}=1.00)$.

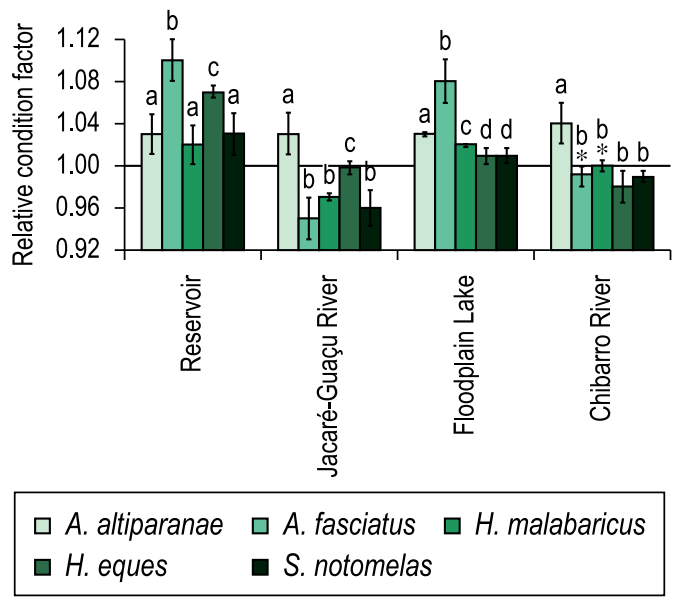

Figure 4. Comparison of the average relative condition factors (with standard error) of the five species, pooling the data of the two periods, in the four habitats: a) The reservoir of Gavião Peixoto Dam; b) Jacaré-Guaçu River; c) floodplain lake; d) Chibarro River. Different letters above bars indicate significant differences among Kn of each species in the habitat (post hoc Tukey test, $P<0.05$ ), and * indicates no statistical difference from 1 (Student's t-test, $P<0.05)$; the gray line indicates the default value $(\mathrm{Kn}=1.00)$. 
(Carvalho and Del-Claro, 2004; Huntingford et al., 2006).

Some features, such as composition, richness, and density of macrophytes may be the main factors responsible for the survival and welfare of juveniles in our study. A relationship between the complexity of macrophyte stands and the welfare of juveniles was evidenced. In the Jacaré-Guaçu and Chibarro rivers, where macrophytes are dominated by one genus of Poaceae, the condition factor of most fishes was lower. In the other two habitats, reservoir and lake, with a much complex composition of the stands of macrophytes, with $c a$. seven taxa, the condition factor was higher for three of the five fish species. The habitat simplification, represented by a grass-dominated one, can lead to a lower fish diversity (Casatti et al., 2009), indicating that complex habitats are more favorable for fish populations.

Aquatic invertebrates are often the most important dietary items of fish juveniles (Meschiatti et al., 2000b; Meschiatti and Arcifa, 2002; Casatti et al., 2003; Crippa et al., 2009; Hahn and LoureiroCrippa, 2006), including the five species analyzed in this study. Macrophytes can harbour a large variety of invertebrates, such as insects, crustaceans, annelids and mollusks, whose abundance and composition vary with the plant species, according to Takeda et al. (2003). These authors report a much lower abundance of invertebrates in the grass Paspalum repens (Poaceae) compared to other plants, such as Pistia stratiotes, Salvinia sp., Eichhornia crassipes, and E. azurea, in the floodplain of the Upper Paraná River. The floating macrophytes, P. stratiotes and Salvinia, have a much higher abundance of associated invertebrates than the others, whose densities can reach values that are approximately 257 and 182 times, respectively, higher than that found in P. repens (calculations based on data of Takeda et al., 2003).

Besides being related to plant species, the abundance of the associated invertebrates can vary seasonally, leading to fluctuations of the food availability to fishes, as observed by Meschiatti and Arcifa (2002). These authors found that invertebrates caught in stands of Eichhornia azurea in the Lake Monte Alegre declined during the cooldry season (June-August), mostly aquatic insects.

The species $A$. altiparanae was the only one whose juveniles were adapted to thrive in all studied habitats. The better adaptation to different situations showed by this species can be explained by various attributes (reviewed in Castro et al., 2004), including the omnivorous feeding behavior, what results in a higher trophic amplitude. The dietary plasticity and the feeding opportunism of $A$. altiparanae can be evidenced in Diogo Lake (Mogi-Guaçu River, SP), where juveniles of this species consumed vegetal matter in relatively high proportion (35\%) within macrophytes (Meschiatti et al., 2000b), and in Americana Reservoir (Atibaia River, SP), where juveniles of this species included also planktonic microcrustaceans in their diet (Arcifa et al., 1991). Casatti et al. (2003) report that, in addition to terrestrial and aquatic insects, young $A$. altiparanae fed also on grass seeds within macrophytes of Rosana Reservoir, Paranapanema River. So, we may hypothesize that in the habitats dominated by grass of the Family Poaceae, the probable lower abundance of invertebrates in the grass stands could be compensated, at least partially, by the inclusion of seeds and a larger proportion of vegetal matter. As a consequence, the condition factors of $A$. altiparanae in the four habitats in Jacaré-Guaçu were similar. However, only further studies on the diet of this species may confirm this inference.

In addition to the influence of macrophytes' complexity on food resources, the lotic condition (Jacaré-Guaçu and Chibarro rivers) is not as favorable to juveniles as semi-lentic and lentic ones (reservoir and floodplain lake). The lower current velocity can favor the establishment of macrophyte stands with greater richness (Camargo et al., 2003), what, as a consequence, can influence positively the development of fish juveniles. Moreover, a higher current velocity will probably end in higher energy expenditure for swimming. In their review, Crook and Robertson (1999) report the lower energetic costs for fishes sheltered within woody debris, due to a lower water velocity in this microhabitat. Therefore, other additional advantage to the lower velocity in some habitats can be the slowing down of the water within the macrophytes (Agostinho et al., 2003), decreasing the energetic costs by fishes.

Other potential limiting factors to the juveniles' welfare within macrophytes include abiotic ones. Fishes are not randomly distributed in the stands of macrophytes, but occupy preferentially their border (Agostinho et al., 2007). In this microhabitat, fishes avoid extreme conditions found in the middle of stands, such as lower oxygen concentrations and $\mathrm{pH}$, but, nevertheless, are still protected from predators. In our study, oxygen and $\mathrm{pH}$ were not limiting for fishes in the border of the stands, where they were collected.

Corroborating studies on the association of fishes and macrophytes, our study evidenced the 
importance of macrophytes for the development of early life stages of fishes. Shelter and food resources provided by macrophytes are fundamental for the fish recruitment and the populations' success. Esguícero and Arcifa (submitted) suggested that shrinking of floodplains, in the Jacaré-Guaçu basin, under the domination of the climatic event La Niña decreased the abundance and diversity of juveniles, during the year, and of adults in the following year. The decline of floodplain areas may directly affect the richness and abundance of macrophytes, lowering the survival of juveniles.

Summarizing, the welfare of most juveniles studied in the habitats of the Jacaré-Guaçu River seems to be primarily influenced by the composition and complexity of the stands of macrophytes, and by current velocity as a direct and indirect factor.

\section{Acknowledgements}

We thank RMC Castro and the Laboratory of Ichthyology of Ribeirão Preto, University of São Paulo, Ribeirão Preto, specially FCP D’Agosta and TNA Pereira who helped in the field work, and CAPES (Coordination of Higher Education Improvement) for a grant to ALHE. We also thank the Graduate Program of Comparative Biology of University of São Paulo for financial support, as well as two anonymous referees for valuable suggestions.

\section{References}

AGOSTINHO, AA., GOMES, LC. and JULIO Jr., HF. 2003. Relações entre macrófitas aquáticas e fauna de peixes. In THOMAZ, SM. and BINI, LM., ed. Ecologia e manejo de macrófitas aquáticas. Maringá: EDUEM. p. 261-280.

AGOSTINHO, AA., THOMAZ, SM., GOMES, LC. and BALTAR, SL. 2007. Influence of the macrophyte Eichhornia azurea on fish assemblage of the Upper Paraná River floodplain (Brazil). Aquatic Ecolology, vol. 41, no. 4, p. 611-619.

ARCIFA, MS. and MESCHIATTI, AJ. 1993. Distribution and feeding ecology of fishes in a Brazilian reservoir: Lake Monte Alegre. Interciencia, vol. 18, no. 6, p. 83-87.

ARCIFA, MS. and NORTHCOTE, TG. 1997. Need for holistic approaches in food web experiments and biomanipulation in tropical lakes: a Brazilian reservoir experience. Verhandlungen des Internationalen Verein Limnologie, vol. 26, no. 2, p. 661-665.

ARCIFA, MS., FROEHLICH, O. and NORTHCOTE, TG. 1988. Distribution and feeding ecology of fishes in a tropical Brazilian reservoir. Memorias de la Sociedad de Ciencias Naturales La Salle, vol. 48, no. 2, p. 301-326.

ARCIFA, MS., NORTHCOTE, TG. and FROEHLICH, O. 1991. Interactive ecology of two cohabiting characin fishes (Astyanax fasciatus and Astyanax bimaculatus) in an euthophic Brazilian reservoir. Journal of Tropical Ecology, vol. 7, no. 1, p. 257-268.

BROWER, JE. and ZAR, JH. 1977. Field and laboratory methods for general ecology. Dubuque: WC Brown. $288 \mathrm{p}$.

CAMARGO, AFM., PEZZATO, MM. and SILVA, GGH. 2003. Fatores limitantes à produçâo primária de macrófitas aquáticas. In THOMAZ, SM. and BINI, LM., ed.). Ecologia e manejo de macrófitas aquáticas. Maringá: EDUEM. p. 59-84.

CARVALHO, LN. and DEL-CLARO, K. 2004. Effects of predation pressure on the feeding behaviour of the serpa tetra Hyphessobrycon eques (Ostariophysi, Characidae). Acta Ethologica, vol. 7, no. 2, p. 89-93.

CASATTI, L., FERREIRA, CP. and CARVALHO, FR. 2009. Grass-dominated stream sites exhibit low fish species diversity and dominance by guppies: an assessment of two tropical pasture river basins. Hydrobiologia, vol. 632, p. 273-283.

CASATTI, L., MENDES, HF. and FERREIRA, KM. 2003. Aquatic macrophytes as feeding site for small fishes in the Rosana Reservoir, Paranapanema River, Southeastern Brazil. Brazilian Journal of Biology, vol. 63, no. 2, p. 213-222.

CASTRO, RMC., CASATTI, L., SANTOS, HF., MELO, ALA., MARTINS, LSF, FERREIRA, KM., GIBRAN, FZ., BENINE, RC., CARVALHO, M. and RIBEIRO, AC. 2004. Estrutura e composição da ictiofauna de riachos da bacia do rio Grande no Estado de Sáo Paulo, Sudeste do Brasil. Biota Neotropica, vol. 4, no. 1, p. 57-95.

CRIPPA, VEL., HAHN, NS. and FUGI, R. 2009. Food resource used by small-sized fish in macrophyte patches in ponds of the Upper Paraná River floodplain. Acta Scientiarum, Biological Sciences, vol. 31, no. 2, p. 119-125.

CROOK, DA. and ROBERTSON, AI. 1999. Relationships between riverine fishes and woody debris: implications for lowland rivers. Marine and Freshwater Research, vol. 50, p. 941-953.

GOMIERO, LM. and BRAGA, FMS. 2003. Relaçấo peso-comprimento e fator de condição para Cichla cf. ocellaris e Cichla monoculus (Perciformes, Cichlidae) no reservatório de Volta Grande, rio Grande-MG/ SP. Acta Scientiarum, Biological Sciences, vol. 25, no. 1, p. 79-86.

HAHN, NS. and LOUREIRO-CRIPPA, VE. 2006. Estudo comparativo da dieta, hábitos alimentares e morfologia trófica de duas espécies simpátricas, de peixes de pequeno porte, associados a macrófitas 
aquáticas. Acta Scientiarum, Biological Sciences, vol. 28 , no. 4, p. 359-364.

HAMMER, Ø., HARPER, DAT. and RYAN, PD. 2001. PAST: paleontological statistics software package for education and data analysis. 1.90.

HUNTINGFORD, FA., ADAMS, C., BRAITHWAITE, VA., KADRI, S., POTTINGER, TG., SANDOE, P. and TURNBULL, JF. 2006. Current issues in fish welfare. Journal of Fish Biology, vol. 68, no. 2, p. 332-372.

LE CREN, ED. 1951. The length-weight relationship and seasonal cycle in gonad weight and condition in the perch (Perca fluviatilis). Journal of Animal Ecology, vol. 20, no. 2, p. 201-219.

LIZAMA, MAP. and AMBRÓSIO, AM. 2002. Condition factor in nine species of fish of the Characidae family in the high Paraná River floodplain, Brazil. Revista Brasileira de Biologia, vol. 62, no. 1, p. 113-124.

LIZAMA, MAP., AMBROSIO, AM. and VAZZOLER, AEAM. 1999. Relação peso-comprimento e estrutura da população de nove espécies da família Characidae na planície de inundação do alto rio Paraná, Brasil. Revista Brasileira de Biologia, vol. 16, no. 3, p. 779-788.

LOWE-McCONNELL, R. 1999. Estudos ecológicos de comunidades de peixes tropicais. São Paulo: EDUSP. $536 \mathrm{p}$.

MESCHIATTI, AJ. and ARCIFA, MS. 2002. Early life stages of fish and the relationships with zooplankton in a tropical Brazilian reservoir: Lake Monte Alegre. Brazilian Journal of Biology, vol. 62, no. 1, p. 41-50.

MESCHIATTI, AJ., ARCIFA, MS. and FENERICHVERANI, N. 2000a. Fish communities associated with macrophytes in Brazilian floodplain lakes. Environmental Biology of Fishes, vol. 58, no. 2, p. 133-143.

MESCHIATTI, AJ., ARCIFA, MS. and FENERICHVERANI, N. 2000b. Ecology of fish in oxbow lakes of Mogi-Guaçu River. In SANTOS, JE. and PIRES, JSR., ed. Estudos integrados em ecossistemas:
Estação Ecológica de Jataí. São Carlos: Rima. vol. 2., p. 817-830.

NAKATANI, K., AGOSTINHO, AA., BAUMGARTNER, G., BIALETZKI,A., SANCHES, PV., MAKRAKIS, M. and PAVANELLI, C. 2001. Ovos e larvas de peixes de água doce: desenvolvimento e manual de identificação. Maringá: EDUEM Nupelia. 378 p.

SÁNCHEZ-BOTERO, JI. and ARAUJO-LIMA, C. 2001. As macrófitas aquáticas como berçário para a ictiofauna da várzea do Rio Amazonas. Acta Amazonica, vol. 31, no. 3, p. 437-447.

TAKEDA, AM., SOUZA-FRANCO, GM., MELO, SM. and MONKOLSKI, A. 2003. Invertebrados associados às macrófitas aquáticas da planície de inundação do Alto Rio Paraná (Brasil). In THOMAZ, SM. and BINI, LM., ed. Ecologia e manejo de macrófitas aquáticas. Maringá: EDUEM. p. 243-260.

THOMAZ, SM., ROBERTO, MC. and BINI, LM. 1997. Caracterização limnológica dos ambientes aquáticos e influência dos níveis fluviométricos. In VAZZOLER, AEAM., AGOSTINHO, AA. and HAHN, NS., ed. A Planície de Inundação do Alto Rio Paraná: aspectos físicos, biológicos e socioeconômicos. Maringá: EDUEM - Nupelia. p. 73-102.

VAZZOLER, AEAM. and MENEZES, NA. 1992. Síntese de conhecimentos sobre o comportamento reprodutivo dos Characiformes da América do Sul (Teleostei, Ostariophysi). Revista Brasileira de Biologia, vol. 52, no. 4, p. 627-640.

VAZZOLER, AEAM., AGOSTINHO, AA. and HAHN, NS. 1997. A Planície de Inundação do Alto Rio Paraná: aspectos físicos, biológicos e socioeconômicos. Maringá: EDUEM - Nupelia. 460 p.

VAZZOLER, AM. 1996. Biologia da reprodução de peixes teleósteos: teoria e prática. Maringá: EDUEM. $169 \mathrm{p}$.

Received: 14 April 2010 Accepted: 08 November 2010 